\title{
Farmers' perception about parasitic otitis in Gyr breed from three states of Brazil ${ }^{1}$
}

\author{
Patrícia V.B. Leite ${ }^{2 *}$, Lucas M. Cunha², Paulo Roberto Oliveira² ${ }^{2}$ Luiza B. Leite ${ }^{2}$ \\ and Romário C. Leite ${ }^{2}$
}

\begin{abstract}
Leite P.V.B., Cunha L.M., Oliveira P.R., Leite L.B. \& Leite R.C. 2012. Farmers' perception about parasitic otitis in Gyr breed from three states of Brazil. Pesquisa Veterinária Brasileira 32(9):855-858. Departamento de Medicina Veterinária Preventiva, Escola de Veterinária, Universidade Federal de Minas Gerais, Av. Antônio Carlos 6627, Pampulha, Cx. Postal 567, Belo Horizonte, MG 30123-970, Brazil. E-mail: patriciabossileite@gmail.com

This study aimed to know the perception of Gir cattle breeders and farm employees about parasitic otitis and practices regarding methods of treatment and control. A questionnaire was applied on specific topics about the disease. The results showed that the otitis occurred in $25(89.3 \%)$ of the 28 farms studied, where the main etiologic agents were the nematodes Rhabditis spp. The majority of the farmers regarded the disease as a serious problem, mainly in cattle older than eight years of age. About half of the respondents did not observe a correlation between season and prevalence of the otitis; however, $30.8 \%$ reported an increase of its incidence during the rainy season. In addition to various methods and products for the rhabditiosis treatment, a lack of standardized preventive or curative protocols was found, suggesting insufficient knowledge about control of the disease.
\end{abstract}

INDEX TERMS: Otitis, prophylactic practices, parasites, nematodes, Rhabditis spp., questionnaire.

RESUMO.- [Percepção de criadores de Gir a respeito da otite parasitária de bovinos em três estados brasileiros, 2009.] Este estudo objetivou conhecer a percepção de criadores e responsáveis técnicos de rebanhos bovinos da raça Gir frente à otite parasitária, inclusive suas práticas relativas aos métodos de controle e tratamento. Utilizou-se um questionário contendo tópicos específicos relacionados à doença. Os resultados mostraram que a otite esteve presente em $25(89,3 \%)$ das 28 propriedades estudadas, sendo os nematóides do gênero Rhabditis o principal agente etiológico encontrado. A maioria dos entrevistados considerou a doença como um sério problema do rebanho, ocorrendo principalmente nos animais com mais de oito anos de idade. Cerca de metade dos entrevistados não observaram correlação entre a época do ano e maior prevalência da doença, por sua vez, $30.8 \%$ deles relataram o aumento da frequência de casos de otite durante a estação chuvosa. Verificou-se, além da grande variedade de métodos e pro-

\footnotetext{
${ }^{1}$ Received on February 28, 2012.

Accepted for publication on May 21, 2012.

${ }^{2}$ Departamento de Medicina Veterinária Preventiva, Escola de Veterinária, Universidade Federal de Minas Gerais (UFMG), Av. Antônio Carlos 6627, Pampulha, Cx. Postal 567, Belo Horizonte, MG 30123-970, Brazil. *Corresponding author: patriciabossileite@gmail.com
}

dutos para o tratamento da rhabditiose, a ausência de padronização dos protocolos preventivos ou curativos, sugerindo conhecimento insuficiente a respeito do seu controle.

TERMOS DE INDEXAÇÃO: Otite, práticas profiláticas, parasitas, nematóides, Rhabditis spp., questionário.

\section{INTRODUCTION}

Parasitic otitis in cattle is mainly caused by rhabditiform nematodes, Rhabditis spp. (Martins Jr et al. 1971), as well as by mites of the genus Raillietia, and may also be associated with a diverse bacterial and fungal microbiota (Duarte et al. 2001a). The Zebu Gir (Bos taurus indicus) breed has phenotypic characteristics which favor the occurrence of the "parasitic otitis complex", in special caused by the nematodes. The peculiar growth of the horns of the Gir breed leads to compression of the external ears, which are long and pendulous. These characteristics prevent ventilation and cause the accumulation of cerumen and secretions within the external auditory canal, providing a favorable environment for the development of microorganisms.

Although the otitis has been observed in Brazil since the 1970 s, with prevalence rates ranging from $78.4 \%$ to $100 \%$, the disease is not well known (Leite et al. 1993, Vieira et al. 1998). The affected cattle can remain without clinical signs 
over a long time or exhibit specific ones, even death (Faccini et al. 1992). The otitis could be responsible for economic losses, although they have not been quantified (Msolla et al. 1993, Vieira et al. 2001, Duarte \& Hamdan 2004).

Some treatments for the otitis are available; however, all without satisfactory results, explained by its constant recurrence, ineffectiveness or costs and even the operational impossibility of methods employed (Leite et al. 1994, Vieira et al. 1998, Verocai et al. 2009).

Considering the significant growth and economic importance of the Gir breed in Brazil (Ledic 2009), research, using a cross-sectional study, was undertaken to understand selected aspects of approach and perception of parasitic otitis. In particular, importance of the disease was studied, as well as the prophylactic and therapeutic practices used in some Gir herds.

\section{MATERIALS AND METHODS}

A questionnaire ${ }^{3}$ on the specific topic of parasitic otitis was applied for farmers or farm employees. It addressed issues such as: the breeding system adopted by farms, the presence of technical assistance, methods used for diagnosing otitis and identifying etiological agents, clinical signs most frequently observed, degree of importance of the disease within the herds, season of the year with the highest frequency of cases, animal category most affected, and special emphasis on the control and treatment methods adopted.

In April/May 2008, the questionnaire was sent by e-mail to 97 members of the Brazilian Association of Gir Dairy Breeders (ABCGIL). An additional 24 farmers was contacted personally on their farms or received the questionnaire during cattle-breeding exhibitions in the cities of Uberaba, Belo Horizonte and Governador Valadares, Minas Gerais. The questionnaires were accompanied by an introduction letter from the staff of the Department of Preventive Veterinary Medicine, School of Veterinary Medicine, Federal University of Minas Gerais, with the objectives of the study, the possible favorable repercussions stemming from future surveys, requesting to fill it out and return to the researcher.

The answers were analyzed by descriptive statisticsl, and the answers related to the methods and medicines used to treat and prevent the disease were put into a database of Microsoft Office Word 2003, and those that were considered similar were grouped and categorized. The method used to synthesize the quantitative and qualitative data aimed to establish a relationship between the results found in this study and the perception and attitudes of the respondents. The associations between answers that might indicate a causal relationship between them were tabulated in contingency tables and compared using the Fisher Exact Test. The quantitative variables that were transformed into proportions had their confidence intervals calculated according to Sampaio (2007), with 95\% significance level.

\section{RESULTS}

Of the 97 questionnaires sent electronically, 16 were answered, with one excluded for incomplete data or absence of some responses that would have compromised the analyses. Thus, from the data returned by e-mail, 15 respondents were analyzed. As for the 24 questionnaires delivered directly to the respondents, 13 were completed and

\footnotetext{
${ }^{3}$ Those who are interested in access to the questionnaire or its use (citing the source), may contact the authors by e-mail or address.
}

returned. Therefore, 28 out of 121 questionnaires were actually completed and analyzed. The information was collected from 25 herds throughout the state of Minas Gerais, in addition to two farms in the state of São Paulo and one in the state of Bahia.

Of the 28 farms involved, only one (3.6\%) has no technical assistance. In the others, there is at least a zootechnist, an agronomist or a veterinarian; veterinarians being the most cited professionals (71.4\% of total). In 24 (96\%) farms assisted by a professional technician, the symptoms were identified and the diagnosis of otitis established; but the interaction between the diagnosis of parasitosis and the presence of technical assistance, showed no significant association ( $p>0.05)$.

In this study, $25(89.3 \%)$ respondents reported cases of otitis on their farms and it was found that the clinical signs of disease are easily recognized. Auricular secretions and lacrimation were considered the most frequent clinical signs; the first symptom was reported by 25 respondents and the second by 21 of them. The occurrence of animals with bowed head, anorexia, lack of motor coordination, and ptosis of eyelid and ear was also mentioned by 17,13 , 10,9 and 8 respondents respectively. The presence of flies around the ears, seizures and ear scratching with hoofs were mentioned once.

In 23 farms, the animals were subjected to at least one diagnostic method to confirm the cause of the otitis. Just the clinical examination was used by the majority of respondents $(87.0 \pm 12.5 \%)$. In two of them, this method was associated with the laboratory test to consolidate the diagnosis. In only one farm, a necropsy was performed to confirm the cause of death. On 10 farms (40\%), the clinical signs of otitis were attributed to the nematodes of the genus Rhabditis. On one of them, the etiological agents were mites of the genus Raillietia, and in another, the nematodes and the mites were in association. Three respondents attributed the otitis cases to bacteria and fungi. Others ten respondents $(40 \pm 18.1 \%)$ have not confirmed the cause of the disease.

The age category indicated as the most predisposing factor was the one for animals older than 8 years, according to the majority $(44.4 \pm 18.4 \%)$ of respondents. There was no report of the disease in animals younger than one year old. In relation to deaths, nearly half of respondents reported having lost animals with otitis.

Regarding systems of livestock production, 39.3\% $( \pm 18.1)$ of the farmers adopted an extensive system. A significant group of farmers $(28.6 \pm 16.7 \%)$ associate extensive breeding with semi-confinement. The others farmers opted for more intensive operations or did not specify the management used.

Concerning the influence of climatic factors on otitis occurrence, $57.7 \%( \pm 18.3)$ of respondents said they had not observed a relationship between the two. However, there was a significant number of reports relating higher frequency of cases of otitis during the rainy season $(30.8 \pm 17.1 \%)$ compared to those who considered the dry season as the most favorable to the disease $(11.5 \pm 11.8 \%)$.

Twenty respondents $(74.1 \%)$ considered parasitic otitis as a serious or very serious problem. Among these, $80 \%$ 
usually engaged in some kind of protocol aimed to control the problem. The relationship between these analyzed groups was statistically significant $(\mathrm{p}<0.05)$ showing that therapeutic measures tend to be applied in those herds where the effect of parasitic otitis has caused damage.

Twenty-five respondents (93\%) reported using some type of procedure to treat the animals with clinical symptoms. The most commonly cited method was ear canal washing, using solutions of alcohol-ether, boric alcohol or iodized alcohol, with or without organophosphates and/or antibiotics. There was significant use of alcohol-ether formulas (34.6\%), along with local antibiotics and organophosphates. For $20 \%$ of farmers, the illness is treated solely with antibiotics.

Eighteen farmers reported using a preventive method to cut down the incidence of the disease on the farm. Among these, 11 used the same protocol as that employed for the treatment of sick animals, which involved washing or cleaning the outer ear with an alcohol-ether solution or boric alcohol, with or without the topical application of an organophosphate insecticide. Besides, three respondents reported using only a local insecticide. A farmer reported keeping special attention to animals that are "shaking head" and others did not define what are the methods used.

Nine of the 18 farmers reported adopting preventive measures once or twice yearly. Two others reported adopting them every three months. Finally, seven farmers adopted these preventive measures at intervals of one or two months. The illness does not disappear completely in any of the herds, but in one of them it had been more than two years without serious cases of parasitic otitis.

\section{DISCUSSION}

The rate of return of the questionnaires distributed via internet was $16.5 \%( \pm 13.7)$, lower than the value found by Foina (2002) who obtained $25.5 \%$. While research conducted in a virtual environment is advantageous in terms of reach, low cost and ease of application, it is limited to the potential respondents who have access to and use of the Internet, frequently it is interpreted as junk mail and thus has a low return rate.

The questionnaire responses were similar and there was no addition of data throughout the study. Therefore, despite the small sample increase the values of the error, basing on the criteria of saturation suggested by Flick (2004); the data were considered representative of the problem under study. And it was important to emphasize that no similar study has been found in the literature survey.

The data suggest that the disease has caused great impact in the respondents' herds. The deaths attributed to the parasitic otitis in half of the farms and the high rate of frequency of rhabditiosis ( $82 \%$ of the herds) confirmed this hypothesis. These values, similar to those cited by Leite et al. (1993), suggests that parasitosis could be considered a serious sanitary problem that requires good scientific knowledge, in particular with respect to the prevention and treatment of affected cattle.

The responses related to the clinical signs most frequently observed in animals with otitis confirmed that the respondents were capable to identify the otitis in chronic or acute stages as already seen by Faccini et al. (1992), Leite et al. (1994) and Vieira et al. (2001). However, the data suggested that the diagnosis was done when the disease was already in an advanced stage, and that animals with mild or unapparent infestation tended to remain not diagnosed and therefore susceptible to chronicity. The knowledge of respondents regarding the interpretation of disease diagnosis and the etiologic agent was very variable; despite of higher technology used in these farms, suggested by the technical assistance, the listed data enabled us to infer total lack of knowledge of the methods employed for diagnosis of the causative agents and lack of basic information about the epidemiology and the control of auditory disorders in cattle.

As previously mentioned, clinical signs of the disease were easily identified and the diagnosis of otitis established, but the interaction between this diagnosis and the presence of professional assistance, showed no significant association ( $p>0.05$ ). Despite the higher technology used on these farms, suggested by the use of technical assistance, the listed data enabled us to infer total lack of knowledge of the causative agents and a lack of basic information about the epidemiology and the control of auditory disorders on the animals.

With respect to the presence of house flies (Musca domestica) around on the sick animals, Jibbo (1966), Msolla et al. (1986) and Obatolu et al. (1999), in studies conducted in Africa, found evidence that these insects would be the nematode vectors. Likewise, in Brazil, Verocai et al. (2007) suggested that $M$. domestica could have an important role in this parasite dissemination. However, there are not enough studies to clarify the mechanism of transmission of the nematodes from one host to another.

With regards to the age at which the cattle are more susceptible, the answers given by the majority of the respondents indicate a higher incidence of clinical otitis in adults, corroborating with the literature (Facury Filho et al. 1990, Leite et al. 1993, Duarte \& Hamdan 2004). On the other hand, there is no scientific evidence which proves the age at which the infestation begins.

This study did not establish a relationship between the presence of parasitic otitis and the production system adopted by the farmers. It was verified that many breeders used an extensive system, coinciding with what is commonly found in the Brazilian cattle livestock. However, the majority of farms have already associated the extensive breeding with semi-confinement or even the complete confinement, in order to increase production, most likely due to the rising cattle commercial value. As the literature showed conflicting results (Jibbo 1966, Vieira et al. 1998, Duarte \& Hamdan 2004) on the subject, it would require further study relating the frequency of cases of bovine parasitic otitis with herd sizes and the type of farming system. And it would be necessary to consider the animals raised exclusively in each production system and also those maintained throughout life in two or more types of management.

This study revealed that farmers are not fully aware of the relationship between the otitis and climatic factors. Surveys conducted in Africa (Jibbo 1966, Obatolu et al. 1999) showed evidence of an increase in incidence of the number of the cases of the disease during the months of highest temperature and humidity without, however, justi- 
fying its disappearance during the dry period. In contrast, studies conducted by Vieira et al. (1998) and Duarte et al. (2001a) in Brazil, have not shown seasonal influence on the prevalence of the disease.

In addition to the wide variety of methods and products used to treat parasitic otitis cited in this study, the data suggested there is controversy and mistakes with respect to the therapeutic treatments in use. For $20 \%$ of farmers, the illness is treated solely with antibiotics. Knowledge of studies that isolated Staphylococcus spp., Corynebacterium bovis, Pseudomonas spp. and Streptococcus spp., and fungi of the genera Malassezia, Candida and Rhodotorula from parasite-infested auricular canals, indicate the need to first identify all of the micro-organisms responsible for this clinical condition and then treat the animals with the appropriate products (Msolla et al. 1986, Duarte et al. 2001b).

The auricular washing with an alcohol-ether solution was the method of treatment selected by the majority of breeders. This option was probably chosen due to the widespread therapeutic trials resulting from the studies by Leite et al. (1994); however, Vieira et al. (1998) showed that these products were most effective when used in vitro.

A factor that should be considered and that is often neglected in the treatment of the disease is the variety of morphological changes that arise as a result of both the parasitic load and the length of time they are present in the auditory canal. According to Duarte \& Hamdan (2004), chronic otitis requires a more extensive therapeutic approach, using systemic antibiotics with non-steroidal anti-inflammatory, for at least three weeks.

In terms of preventing the otitis caused by Rhabditis spp., it seems that the majority of respondents share the belief that washing the outer ear is a preventive strategy and not a "curing" procedure which decreases the local population of parasites but does not eliminate the illness from the herd. This was also observed by Jibbo (1966) who reported that it was common to adopt current methods in an attempt to block the transmission cycle by using different products, such as organophosphates, pyrethroids and even antibiotics.

This study showed that the frequency of the use of the preventive methods varied between breeders, allowing to infer that the size of the farm and the damage caused by the disease, influenced this decision. There were no scientific studies on which method or frequency would be ideal to achieve strategic control of parasitic otitis.

The knowledge and the control measures reported by the respondents seem to be insufficient to eradicate the parasitic otitis since they are still present on the majority of the farms studied. Furthermore, although this and other studies had indicated that this disease can be considered a serious sanitary problem in Gir herds, the surveys conducted to date do not provide sufficient information to answer important questions, delaying the development of an appropriate method for the prevention and treatment of this disease.

Acknowledgements.- To Fundação de Amparo à Pesquisa do Estado de Minas Gerais (FAPEMIG), Coordenação de Aperfeiçoamento de Pessoal de Nível Superior (CAPES), Conselho Nacional de Desenvolvimento Científico e Tecnológico (CNPq), and to Informação Genético-Sanitária da Pecuária Brasileira (INCT) for financial support. To Associação Brasileira de Cria- dores de Gir Leiteiro (ABCGIL) for providing the electronic addresses of its members, and especially to colleagues of the parasitic diseases laboratory, Luisa N. Domingues, Arildo P. Cunha, Ana C.P.P. Bello, and Daniel S. Rodrigues, for helping with data collection and statistical analysis.

\section{REFERENCES}

Duarte E.R. \& Hamdan J.S. 2004. Otitis in cattle: An aetiological review. J. Vet. Med. B 51:1-7.

Duarte E.R., Melo M.M. \& Hamdan J.S. 2001a. Epidemiological aspects of bovine parasitic otitis caused by Rhabditis spp. and/or Raillietia spp. in the state of Minas Gerais, Brazil. Vet. Parasitol. 101(1):45-52.

Duarte E.R., Resende J.C.P., Rosa C.A. \& Hamdan J.S. 2001b. Prevalence of yeasts and mycelial fungi in bovine parasitic otitis in the State of Minas Gerais, Brasil. J. Vet. Med. B 48:631-635.

Faccini J.L.H., Fonseca A.H., Costa A.L. \& Leite R.C. 1992. Distribuição geográfica e prevalência das espécies do gênero Raillieitia Trouessart em bovinos no Brasil. Revta Bras. Parasitol. Vet. 1(2):109-110.

Facury Filho E.J., Guimarães A.M., Oliveira P.R. \& Garcia A.M. 1990. Ocorrência de otite parasitária em um rebanho da raça Gir, no município de Betim, Minas Gerais. Anais $4^{\circ}$ Congresso Mineiro de Medicina Veterinária, Belo Horizonte. Escola de Veterinária da UFMG, Belo Horizonte, p.95.

Flick U. 2004. Uma Introdução à Pesquisa Qualitativa. 2ª ed. Bookman, Porto Alegre. 312p.

Foina A.G. 2002. Métodos de Aquisição de dados quantitativos na internet: o uso da rede como fonte de dados empíricos. Ciênc. Tróp., Recife, 30(2):283-296.

Jibbo J.M.C. 1966. Bovine parasitic otitis. Bull. Epizoot. Dis. Afr. 14:59-63.

Ledic I.L. 2009. O Gir leiteiro 'puro': uma realidade na América Latina. Disponível em <http://girbrasilartigo1.blogspot.com/2009/03/0-gir-leiteiro-puro-uma-realidade-na.html> Acesso em 2 jul. 2009.

Leite R.C., Nunes V.A., Nunes I.J., Costa A.L., Faccini J.L.H. \& Lopes C.W.G. 1993. Otite parasitária bovina por nematódeos rhabditiformes: aspectos epidemiológicos e clínicos. Revta Bras. Med. Vet. 15(2):49-51.

Leite R.C., Leite R.C. \& Faccini J.L.H. 1994. The diagnosis and treatment of bovine parasitic otitis caused by rhabditiform nematodes. Revta Bras. Parasitol. Vet. 3(1):69-70.

Martins Jr W., Nunes I.J., Ribeiral L.A., Rosaz C.E.E. \& Nunes V.A. 1971. Nota sobre a ocorrência da Rhabditidae (Nematoda, Rhabditida) relacionados com otite em bovinos na região geo-econômica de Brasília/DF. Ciência e Cultura 23(Supl.):248-249.

Msolla P., Matafu E.P.M. \& Monrad J. 1986. Epidemiology of bovine parasitic otitis. Trop. Anim. Health Prod. 18:51-52.

Msolla P., Semuguruka W.D., Kasuku A.A. \& Shoo M.K. 1993. Clinical observations on bovine parasitic otitis in Tanzania. Trop. Anim. Health Prod. 25(1):15-18.

Obatolu U.U., Pjunkenyi D.M. \& Ushe T. 1999. A retrospective epidemiological study of parasitic otitis in cattle in the south-east Lowveld of Zimbabwe. Zimbabwe Vet. J. 30:19-24.

Sampaio I.B.M. 2007. Estatística Aplicada à Experimentação Animal. Fundação de Ensino e Pesquisa em Medicina Veterinária e Zootecnia, Belo Horizonte. 211p.

Verocai G.G., Fernandes J.I., Correia T.R., Melo R.M.P.S., Alves P.A.M. \& Scott F.B. 2007. Otite parasitária bovina por nematóides rhabditiformes em vacas Gir no estado do Rio de Janeiro, Brasil. Revta Bras. Parasitol. Vet. 16(2):105-107.

Verocai G.G., Fernandes J.I., Correia T.R., Melo R.M.P.S., Alves P.A.M., Scott F.B. \& Grisi L. 2009. Inefficacy of albendazole sulphoxide and ivermectin for the treatment of bovine parasitic otitis caused by rhabditiforme nematodes. Pesq. Vet. Bras. 29(11):910-912.

Vieira M.C.M., Silva L.A.F., Borges N.C., Araujo J.L.B., Santin A.P.I. \& Silva E.V. 1998. Estudo da prevalência de otites clínicas por Rhabditis sp. em bovinos da raça Gir no estado de Goiás. Anais Esc. Agron. Vet., Goiânia, 28(2):19-29.

Vieira M.C.M., Silva L.A.F., Araujo J.L.B., Andrade M.A., Fioravanti M.C.S. \& Silva E.V. 2001. Parasitic otitis by rabditiform nematode in Gir cattle: Evaluation of treatments. Ciênc. Anim. Bras. 2(1):51-55. 